\title{
Determinants of Goodwill Impairment Loss Recognition*
}

Mara Vogt

Fundação Universidade Regional de Blumenau, Programa de Pós-Graduação em Ciências Contábeis, Blumenau, SC, Brazil.

Caroline Sulzbach Pletsch

Universidade do Estado de Santa Catarina, Departamento de Ciências Contábeis, Ibirama, SC, Brazil.

Vania Regina Morás

Fundação Universidade Regional de Blumenau, Departamento de Ciências Contábeis, Blumenau, SC, Brazil.

Roberto Carlos Klann

Fundação Universidade Regional de Blumenau, Programa de Pós-Graduação em Ciências Contábeis, Blumenau, SC, Brazil.

Received on 05.27.2015 - Desk acceptance on 06.19.2015 - $5^{\text {th }}$ version approved on 06.26 .2016

\section{ABSTRACT}

This study aimed to verify the determinants of goodwill impairment (GOODWIMP) loss recognition in Brazilian companies. For this, a descriptive and documentary study was carried out in which information was collected from databases and explanatory notes using a quantitative approach. The study sample was comprised of Brazilian companies listed on the Thomson database, totaling 91 companies and 346 observations. Data were collected from 2011 to 2014. For the treatment and analysis of the data, logistic regression with panel data was used. The results show that the factors change in management (CHMAN), book-to-market (BM), number of cash generating units (CGU), variation in return on assets $(\triangle \mathrm{ROA})$ and goodwill (GOODW) were significant in determining GOODWIMP losses. These findings indicate that in addition to economic factors, managers' actions are associated with the recognition of such losses, which can be characterized as incentives for earnings management (EM) practices. Therefore, it is generally concluded that the GOODWIMP losses recognized in the companies analyzed may not only have been used to reduce their assets to recoverable amounts, but also to achieve results consistent with the objectives of managers.

Keywords: determinants, economic factors, incentives for earnings management, impairment, goodwill.

*Paper presented at the XV USP Controlling and Accounting Congress, São Paulo, SP, Brazil, July 2015. 


\section{INTRODUCTION}

While carrying out a review of empirical studies regarding the impairment test, Zandonai and Borba (2009) summarize some definitions in a table, both from Brazilian as well as international authors. There are definitions related to the difference between the accounting value and fair value of assets, when the latter is lower, such as those from Meeting and Luecke (2002), Santos, Schmidt, and Machado (2003), and Seetharaman, Sreenivasan, Sudha, and Yee (2006), as well as others related to the loss of ability to generate future economic benefits, such as those from Alciatore, Easton, and Spear (2000), and Raupp and Beuren (2006).

In the regulatory context, impairment consists of the devaluation of assets recognized in accounts when the accounting value of an asset, after depreciation, amortization, or depletion is greater than its recoverable value, obtained from the higher value between fair value net of sales expenses and its value in use (CPC, 2010).

Loss from asset recoverability or impairment has been a recurring topic of discussion, whether in the academic field, with the publication of various articles in recent years, or in the regulatory environment, with elaborations and alterations of the rules by various regulatory bodies, but notably by the Financial Accounting Standards Board (FASB), the US regulator, and the International Accounting Standards Board (IASB), which is international in scope. From 2001, with the Enron and WorldCom company scandals, in which one of the frauds was related to overvaluation of assets, according to Andersson and Wenzel (2014), the impairment test has come to receive even more attention.

In Brazil, this issue became more evident after the process of accounting convergence with the IASB standards, primarily after the publication of Technical Pronouncement CPC 01 by the Accounting Pronouncements Committee (CPC, 2010). Souza, Borba, and Zandonai (2011) highlight that, depending on the value, the recognition of a loss can cause a significant impact on the earnings for a financial period. The disclosure of considerable losses from impairment by Petrobras in 2015 and 2016 helps to exemplify the importance of such losses to the market, which can significantly affect both the earnings and equity of companies, as well as future cash flow projections.

The issue of goodwill impairment gained relevance after an increase in business combination transactions and the treatment of the resulting goodwill for future returns. Zang (2008) highlights that amortizing a fixed amount of goodwill over the course of its useful life can result in an inappropriate measure of losses in its recoverable value. Thus, the adoption of the impairment test would aim to bring a more realistic view of goodwill values. However, the care taken in applying this goodwill test should be greater than that for other assets, since this is the only asset not directly associated with specific identifiable rights, and it is inseparable from the company as a whole.

In Brazil, the change from periodic amortization to applying the impairment test can also be considered as an important change in terms of accounting practices, which has resulted in an increase in manager discretion, and, consequently, their responsibility for impairment losses recorded against goodwill values. Goodwill impairment losses recognized in the first years after business combinations are related to the overvaluation of assets acquired in the combination process (Gu \& Lev, 2011; Olante, 2013).

Goodwill is conceptualized by Technical Pronouncement CPC 04 (CPC, 2010) as goodwill resulting from recognized future returns in a combination of businesses, which represents future economic benefits generated by acquired assets that are not recognized individually. Thus, it is necessary to evaluate whether there has been a reduction in the recoverable value of goodwill, or rather, verify whether there has been a reduction in expected economic benefits. The impairment for this asset is calculated as the difference between its accounting value and its recoverable value. Lander and Reinstein (2003) highlight that if the accounting value of goodwill exceeds its recoverable value, it means that it has devalued, and in this case an impairment loss should be recognized.

The recoverable value of goodwill is not something that is simple to estimate. It requires deep knowledge regarding the methods for evaluating tangible and intangible assets (Seetharaman et al., 2006). Li, Shroff, Venkataraman, and Zhang (2011) highlight that there is subjectivity in estimating impairment losses based on fair values, which can reduce the quality of accounting information. Despite subjectivity being inherent to accounting itself, these authors highlight that the calculation of goodwill impairment losses may be too complex, with the need for allocating goodwill to various cash generating units and calculating the present value of future benefit flows for these units.

As well as this technical difficulty due to subjectivity, company management can use goodwill impairment in order to underestimate or even fail to recognize existing losses (Abughazaleh, Al-Hares, \& Roberts, 2011). Impairment losses, because they influence final company earnings, can favor earnings management (EM), due to the fact that they involve estimates which can be altered in order to achieve desired company earnings (Amaro, Bachmann, \& Fonseca, 2013).

In this context, research has been carried out with the aim of studying the recognition of goodwill impairment (treated from here on as GOODWIMP) losses by companies. On a national level, this research includes studies related to the disclosure of information regarding impairment tests 
(Souza et al., 2011; Albani \& Almeida, 2012; Machado, Cruz, Takamatsu, \& Lima, 2013; Barbosa, Consoni, Scherer, \& Clemente 2014); related to the impact of transactions which involve goodwill in total assets and its evolution in relation to sales, to the number of employees, and to total asset values (Pinheiro, 2014); and related to the interference of ownership concentration in decision making regarding applying the GOODWIMP test in Brazilian companies (Santos, Dani \& Klann, 2015).

On an international level, studies that stand out include those regarding the causes of asset impairment (Francis, Hanna, \& Vincent, 1996); evidence of GOODWIMP in financial statements (Hayn \& Hughes, 2006); how managers calculate GOODWIMP (Zang, 2008); the way in which companies carry out impairment tests (Petersen \& Plenborg, 2010); and whether GOODWIMP losses or reversals in them are used for earnings management (Duh, Lee, \& Lin, 2009; Abughazaleh et al., 2011).

There is a noticeable gap in the research carried out in these studies regarding the determinants of GOODWIMP loss recognition, coverage of which is not observed much in the literature, especially the Brazilian literature. Moreover, the studies that have been developed present contradictory results regarding these determinants. Schneider (2001) highlights that in companies with more than one cash generating unit (CGU), more impairment tests are likely to be carried out, which would increase the probability of loss recognition. Moreover, for Abughazaleh et al. (2011), the number of CGUs can be used to reduce or avoid GOODWIMP loss recognition. For example, if a company allocates most of the goodwill to CGUs that have greater recoverable values than their accounting values, it will reduce the likelihood of GOODWIMP losses. Perceiving the scarce evidence or alignment in results, Zang (2008) showed that impairment losses are greater when a recent change in management has occurred, since managers can justify such losses as being adjustments resulting from previous management. On the other hand, for Francis et al. (1996), changes in management can be related to low impairment losses, so that managers can have more highly valued assets under their management.

Abughazaleh et al. (2011) highlight that GOODWIMP losses can result from economic factors related to firm performance, management disclosure incentives, and restrictions on such incentives, such as those imposed by governance mechanisms. It therefore follows that GOODWIMP can result from a normal expected relationship between loss recognition and economic aspects linked to firms, such as for example a greater number of CGUs, which increases the probability of loss recognition.

However, it may also occur that these (incentive) variables are used opportunistically by management for earnings management, given the subjectivity and complexity involved in calculating GOODWIMP losses. This is the case, for example, of managers using a greater number of CGUs to manage the allocation of goodwill and being able to control the value of the loss to be recognized.

In light of this, and considering that economic factors and incentives for earnings management can affect companies' decisions when recognizing such losses or not, this study aims to verify the determinants of GOODWIMP loss recognition in Brazilian companies.

The results of this study show that the factors change in management (CHMAN), book-to-market (BM), number of cash generating units (CGU), variation in return on assets $(\triangle \mathrm{ROA})$, and goodwill (GOODW) were significant in determining GOODWIMP losses. These results provide indications that the companies studied used GOODWIMP losses for earnings management, considering that one of the two proxies employed in the study to capture this behavior (CHMAN) was shown to be significant.

The study is warranted due to it using a set of identified variables based on the literature review which differ from the other studies already carried out in Brazil. Because of this, there is the possibility making a contribution to current knowledge regarding the topic, providing empirical evidence regarding factors that can help to explain GOODWIMP loss recognition in Brazilian companies. Additionally, as impairment losses influence company earnings, this study can be considered as apt for the area of research related to earnings management (Martinez, 2006; Amaro et al., 2013).

Another study contribution involves the divergent results found among Brazilian companies in comparison to international studies, which indicates that GOODWIMP loss recognition in Brazil is founded on two main questions: changes in management, which provides indications of the use of such losses for practicing EM; and goodwill values, which can indicate overvaluations of this asset at the time of business combinations.

The study can also help regulatory bodies, investors, and other users of accounting information, showing whether managers use GOODWIMP losses for company earnings management, which results in direct implications for the quality of the accounting information published by organizations.

By verifying incentives for GOODWIMP loss recognition, regulatory bodies can, for example, create mechanisms that mitigate such practices, by means of alterations in the standards that address goodwill recognition and its impairment (CPC 01, CPC 04, and CPC 15). As the study indicates a positive relationship between changes in management and GOODWIMP loss recognition, the Brazilian Securities Commission (CVM) could, for example, monitor such processes in companies with this characteristic (a recent change in management) more intensely.

By demonstrating which economic factors are related to such losses, the various stakeholders can make more effective 
decisions regarding the allocation of their funds, based on an understanding of the factors determining GOODWIMP loss recognition. Investors could, for example, include economic factors in their projections and incentives for practicing EM that could lead to GOODWIMP loss recognition, mitigating future losses in their investments.

\section{GOODWILL IMPAIRMENT LOSSES}

Impairment loss has already been conceptualized by various authors, but they basically follow two lines, one related to fair value and the other to future cash flow from assets. One trend indicates the existence of impairment losses when the fair value of assets is lower than their accounting value, such as in Meeting and Luecke (2002), Santos et al. (2003), and Seetharaman et al. (2006). The second trend addresses the loss in ability to generate future economic benefits, such as in Alciatore et al. (2000), and Raupp and Beuren (2006). In any event, it is understood that a loss should be recorded whenever an asset is recorded in the accounts with a higher value than its recoverable value, whether in function of its fair value (considering an asset sale, for example), or in function of its value in use (considering the future cash flows that this asset can generate during its useful life).

However, this question becomes more complex when the asset in question is goodwill, since according to Zang (2008), a unique asset is concerned which is not directly associated with specific identifiable rights and is inseparable from the company as a whole. Thus, it cannot be sold separately from the company, which makes calculating of its fair value (separately) impossible. Calculating future benefit flows generated by it can also be difficult, since it can be included in different cash generating units.

It is important to bear in mind that goodwill is an asset which represents the future economic benefits that result from other assets that are acquired in business combinations and are not identified individually and recognized separately [CPC 15] (CPC, 2011).

Given the convergence of Brazilian accounting standards with international accounting standards, goodwill should no longer be amortized, but rather, have its value tested by means of impairment (Iudícibus, Martins, Gelbcke, \& Santos, 2010). This should occur, according to Technical Pronouncement CPC 01, at least once a year, independent of whether or not there is an indication for a reduction in recoverable value. For this, according to CPC 15, the acquirer should measure goodwill by means of the recognized value on the date of acquisition, minus the accumulated loss from reductions in the recoverable amount.

This GOODWIMP loss should be recorded by managers if they detect that the recoverable amount of a cash generating unit is below the accounting value. However, some managers can exaggerate, underestimate, or even fail to recognize the existing loss, depending of the way in which goodwill is allocated to the CGUs (Abughazaleh et al., 2011).

Therefore, management has the flexibility to determine the recording of goodwill, since the rules allow a certain degree of judgment on the part of managers regarding measurement and recording. As an example of this judgment, the allocation of goodwill to CGUs can be mentioned. If managers want to show little or no loss, they can allocate goodwill to a CGU in which the implicit fair goodwill value is sufficiently high in order to pass the recoverability test (Zang, 2008).

Moreover, it is worth highlighting that the subjectivity in estimating impairment losses, sometimes with fair values that are not verifiable, can reduce the content of information regarding fair value. Prices quoted on the market end up providing the best evidence regarding fair value. However, in the absence of a market quotation, this can be estimated using present value or another evaluation technique. Thus, fair value estimates, for most companies, are based on CGU cash flow projections (Li et al., 2011).

This perception is collaborated by Niyama, Rodrigues, and Rodrigues (2015), who claim that in almost all cases recoverable goodwill values are calculated using the value of estimated future cash flows, derived from the use of a set of assets, or rather, from a cash generating unit. This can imply value judgments, such as: understanding of what constitutes a cash generating unit, future cash flow estimates, and the discount rate to be used.

In light of the above, the importance of addressing the question of GOODWIMP losses is verified, given that goodwill values recorded in business combination transactions are often significant, and the recognition of losses in this type of asset can affect company results, equity, and future cash flows. Considering that amortization of goodwill by future returns no longer exists, which led to a certain predictability of the impact of the economic losses from goodwill in earnings, impairment tests, although they can result in less predictable losses, seek to bring goodwill values to accounting statements that are more compatible with their potential for generating future economic benefits.

In light of the flexibility in determining the recording of goodwill, national and international studies have been carried out in order to study goodwill impairment loss recognition. The main studies are thus addressed in chronological order.

Francis et al. (1996) studied the causes of asset impairment. The results showed that the book-to-market and return on assets variables were significant in explaining asset impairment. They also found that impairment losses 
are greater and more frequent if there has been a recent change in management.

GOODWIMP was analyzed in the study by Hayn and Hughes (2006) in acquired companies, and the authors found little evidence in the financial statements. This indicates that these statements do not allow users to evaluate adequacy in relation to GOODWIMP. Thus, the non-recognition of this impairment can result in incorrect balances.

Zang (2008) analyzed how managers calculate GOODWIMP and verified that companies that had experienced a recent change in management showed higher impairment values, while lower impairment losses were observed in more leveraged companies. This demonstrates that GOODWIMP transmits relevant information, such as a negative view regarding future transactions or adverse effects regarding a company's contracts.

A study regarding reversal of impairment losses was also carried out by Duh et al. (2009). The authors examined whether in companies listed on the Taiwan Stock Exchange the reversal of impairment losses provides an opportunity for earnings management. They verified that companies that recognize more impairment losses are more likely to reverse these losses, in order to avoid a fall in profits.

Petersen and Plenborg (2010) analyzed the way that companies listed on the Copenhagen Stock Exchange carried out impairment tests, and the factors that can explain why some companies are not totally in agreement with the rule. The results showed that there are still incoherencies in the application of the rule concerning the reduction in the recoverable value of assets, both in the way they define a cash generating unit and in the recoverable amount estimate.

Verifying whether GOODWIMP is associated with CEO changes and income smoothing was the aim of the study by Abughazaleh et al. (2011). The results also indicated that devaluations in goodwill were strongly associated with governance mechanisms, suggesting that managers are more likely to carry out their function and transmit private information regarding company performance, instead of acting in an opportunistic way and not recognizing such losses in the earnings.

In Brazil, Souza et al. (2011) verified whether in companies listed on the Ibovespa Index that recognized losses in recoverable asset amounts in 2008 , these companies followed the disclosure standards contained in CPC 01 Reduction in Recoverable Amount of Assets. They found that, of the companies analyzed, none completely met all of the CPC 01 requirements. The most disclosed information was the loss amount and the way of measuring the recoverable amount.

Albani and Almeida (2012) investigated to what extent the CPC 01 requirements were met in BM\&FBOVESPA New Market companies in 2010. Out of 125 companies, 106 disclosed the carrying out of impairment tests, and of these, few met the minimum disclosure requirements.

The study by Machado et al. (2013) verified whether companies that recognized impairment losses or reversals presented different levels of disclosure in relation to companies that did not recognize them. The sample corresponded to Brazilian companies listed on the New Market in 2009. It was found that the companies that recognized such losses or reversals presented a higher level of disclosure.

Barbosa et al. (2014) investigated whether publiclytraded Brazilian companies disclosed information regarding GOODWIMP tests from 2009 to 2011. The results demonstrated that in 2009 most of the companies did not publish any information, coming to adopt such procedures in 2010 and in 2011.

Pinheiro (2014) analyzed the impact of transactions that involve goodwill in total assets, and its evolution compared to sales, number of employees, and the value of total assets. The results revealed that six companies recorded GOODWIMP losses, with evidence of manipulation of earnings in these cases. In two companies goodwill is seen as an asset of no importance. In the other companies analyzed, no evidence was observed of earnings manipulation. Santos et al. (2015) did not find evidence of the influence of the concentration of ownership and corporate governance in decision making at Brazilian companies in relation to applying the GOODWIMP test, nor significant connections between the test and the disclosure of further information regarding goodwill.

Based on the above, it is verified that studies regarding GOODWIMP, mainly involving its determinants, objectives, and consequences, are still incipient. Some studies related to EM were identified, but the results are still contradictory or lack greater investigation. 


\section{DEVELOPMENT OF THE HYPOTHESES ASSOCIATED WITH THE}

\section{DETERMINING FACTORS AND INCENTIVES FOR GOODWILL IMPAIRMENT}

\section{LOSS RECOGNITION}

The book-to-market (BM) variable represents the difference between a company's market value and its accounting value (Chen \& Zhao, 2004). It can also represent a measure of return on shares (Zang, 2008) and indicate company growth (Jarva, 2009). Organizations with higher $\mathrm{BM}$ are those that present higher GOODWIMP losses (Zang, 2008). Abughazaleh et al. (2011) verified that the book-tomarket variable was significantly correlated with goodwill impairment. There is a tendency that the higher the bookto-market, the greater the recoverable amount losses will be (Strong \& Meyer, 1987; Peetathawatchai \& Acaranupong, 2012), since the closer the book value of NE to company market value, the greater the probability that its assets may be overvalued or not be totally recoverable. In this case, the first asset to be devalued due to impairment within a cash generating unit will be goodwill (CPC 15). Thus, based on these studies, the first hypothesis of this study is presented:

$\mathbf{H}_{1}$ : There is a significant and positive relationship between book-to-market and GOODWIMP loss recognition.

Cash Generating Units (CGU) can have an impact on the probability of an impairment loss. Companies with more than one CGU should carry out impairment tests (Schneider, 2001). Companies with various cash generating units can increase GOODWIMP impairment losses by allocating most goodwill to units with recoverable amounts lower than their accounting values. On the other hand, this variable can be used to reduce or avoid GOODWIMP losses, allocating it to cash generating units with recoverable amounts greater than their accounting values, thus reducing the likelihood of losses (Abughazaleh et al., 2011). As the previous studies present contradictory results with regards to the influence of CGUs on GOODWIMP loss recognition, the second study hypothesis is presented, without predicting the expected sign for the relationship.

$\mathbf{H}_{2}$ : There is a significant relationship between the number of Cash Generating Units and GOODWIMP loss recognition.

The revenues (REV) variable corresponds to volume of business and represents a gross measure of company performance, which is measured by the variation in total company revenues (Abughazaleh et al., 2011). In the study by these authors, the revenues variable presented a negative sign with GOODWIMP.

A variation in total revenues can influence, for example, projections for future economic benefits from assets by calculating their value in use. Thus, the greater the variation in revenues, the higher the future cash flow projection, leading to a greater value in use. In this case, there would be a lower probability of impairment loss recognition, since value in use would tend to be greater than accounting value.

Thus, it is expected that the greater revenues are, the greater cash flows will be for calculating goodwill value in use, which influences the non-recognition of impairment losses. In light of the above, the third hypothesis of this study is presented:

$\mathbf{H}_{3}$ : There is a significant and negative relationship between revenues and GOODWIMP loss recognition.

The "variation in operating cash flow" $(\triangle \mathrm{OCF})$ variable looks for performance attributes that are related with money (Riedl, 2004). It is expected that variations in cash flow are a primary factor in determining the value of GOODWIMP losses, since value in use estimates are highly dependent on cash flow projections.

Thus, a reduction in cash flow projections would result in a lower value in use, which would raise the likelihood of impairment loss recognition (Abughazaleh et al., 2011). The opposite would also be true - with greater cash flows, value in use would also be raised, reducing the recognition of such losses.

These authors verified that the "cash flow" variable was negatively and significantly related to GOODWIMP. A negative relationship is expected, because the greater cash flow is, the greater an asset's value in use will be (in the case of goodwill), and consequently, the lower the probability that a loss has to be recognized. Thus, this gives the fourth hypothesis of this study:

$\mathbf{H}_{4}$ : There is a significant and negative relationship between variations in operational cash flow $(\triangle \mathrm{OCF})$ and GOODWIMP loss recognition.

The value of goodwill (GOODW) demonstrates that a company with a greater quantity of assets can report more GOODWIMP losses, due to the quantity of assets exposed to the tests being greater. Goodwill is a unique asset, that is not directly associated with specific identifiable rights and is inseparable from the organization as a whole (Zang, 2008). In their study, Abughazaleh et al. (2011) found significance in the goodwill variable in relation to goodwill impairment. The justification for the positive relationship resides in the fact that the greater the value of goodwill, the greater the risk of a company suffering losses in its recoverability. In light of the context presented, the fifth hypothesis of this 
study was elaborated:

$\mathbf{H}_{5}$ : There is a significant and positive relationship between the value of goodwill and GOODWIMP loss recognition.

Another variable that may be related to GOODWIMP losses is variation in return on assets (ROA). According to Francis et al. (1996) and Zang (2008), companies with a greater variation in ROA are subject to lower GOODWIMP losses, since companies with higher ROAs tend to be more highly valued on the market, increasing with this the fair value of their assets. Consequently, the greater the fair value of their assets, the lower the likelihood of impairment losses occurring. Souza (2011) highlights that companies with greater profitability also tend to disclose lower losses, since these attract investor attention more, which could adversely affect the price of their securities on the market.

Rield (2004) and Abughazaleh et al. (2011) highlight the same effect, but in the opposite direction - companies with a smaller variation in ROA tend to have a greater amount of impairment asset losses. In the study by Abughazaleh et al. (2011), the Return on Assets (ROA) variable was negatively related to GOODWIMP. Thus, the sixth study hypothesis is established:

$\mathbf{H}_{\mathbf{6}}$ : There is a significant and negative relationship between variation in ROA and GOODWIMP loss recognition.

As well as the determinant variables listed above, which may have a natural relationship with GOODWIMP loss recognition, there is also the possibility of managers using such losses as a way of managing company earnings. In this case, GOODWIMP losses would not only derive from the particular characteristics of each company, such as returns, cash flow levels, and goodwill values, but also from opportunistic behavior on the part of managers. Based on the study by Zang (2008), the leverage (LEV) and change in management (CHMAN) variables were used to evaluate the possible incentives for earnings management in impairment loss recognition.

Based on the Level of Debt Hypothesis (Watts \& Zimmerman, 1986), firms with a high level of indebtedness tend to make accounting choices which maximize their earnings. Thus, it is proposed that leveraged companies are more likely to underestimate GOODWIMP impairment losses, especially if their level of indebtedness is limited by restrictive clauses, or so-called contractual covenants (Zang, 2008; Abughazaleh et al., 2011).

According to Zang (2008), high GOODWIMP impairment loss values have a negative impact on the financial structure of companies, reducing their net equity. The results of his study showed that GOODWIMP losses are lower when companies are highly leveraged. Thus, the seventh study hypothesis is presented:

$\mathbf{H}_{7}$ : There is a significant and negative relationship between financial leverage and GOODWIMP loss recognition.

Consistent with Contract Theory (Watts \& Zimmerman, 1986, 1990; Holthausen, 1990; Christie \& Zimmerman, 1994), managers may overvalue, undervalue, or even fail to recognize losses, depending on their incentives. Thus, companies that experience changes in management may show a tendency to report greater GOODWIMP losses in order to reduce future losses. New management may recognize greater GOODWIMP losses, attributing their cause to the bad decisions of their predecessors (Zang, 2008). The results from Francis et al. (1996) and Zang (2008) indicate that impairment losses are greater when a recent change in management has occurred. Thus, the eighth study hypothesis is established:

$\mathbf{H}_{8}$ : There is a significant and positive relationship between changes in management and GOODWIMP impairment recognition as an incentive for earnings management.

\section{METHODOLOGICAL PROCEDURES}

\subsection{Population and Sample}

The population of the study consisted of publicly-traded Brazilian companies listed on the Thomson One Banker ${ }^{\oplus}$ database which presented recognized goodwill, totaling 98 companies. Seven companies that did not have data necessary for the study were excluded. The sample used was thus one with 91 companies, covering the analysis period from 2011 to 2014, resulting in 346 observations. It is worth noting that not all of the companies presented data for all of the analysis period, thus opting to use an unbalanced panel, in order not to limit the study sample even more. It is understood that this option does not adversely affect the results, given that around only $5 \%$ of the observations (18 from a total of 364 ) were excluded, and some contained atypical data (outliers) that could bias the results.

\subsection{Data Collection and Analysis}

The data collection occurred using the Thomson One Banker ${ }^{\circledR}$ database, in which data were collected for the Book to Market (BM), revenues (REV), variation in operational cash flow $(\triangle \mathrm{OCF})$, variation in return on assets $(\triangle \mathrm{ROA})$, goodwill value (GOODW), and financial leverage (LEV) variables.

The cash generating unit (CGU) variable was verified 
in the explanatory notes, while the change in management (CHMAN) variable was verified in the reference forms of the sample companies. The GOODWIMP dependant variable was obtained based on analysis of the Explanatory Notes of the sample companies, collected from the BM\&FBOVESPA website. Table 1 presents the study variables.

Table 1 Study variables

\begin{tabular}{|c|c|c|c|c|c|}
\hline \multicolumn{2}{|c|}{ Variables } & Description & Formula & Collection & Authors \\
\hline \multicolumn{6}{|c|}{ Dependant Variable } \\
\hline \multicolumn{2}{|c|}{ GOODWIMP } & $\begin{array}{l}\text { Goodwill impairment } \\
\text { loss }\end{array}$ & $\begin{array}{l}\text { Dummy variable: } 1 \text { in periods of } \\
\text { recorded goodwill impairment } \\
\text { losses, and } 0 \text { otherwise }\end{array}$ & $\begin{array}{c}\text { BM\&FBOVESPA - Financial } \\
\text { Statements - } \\
\text { Explanatory Notes }\end{array}$ & $\begin{array}{c}\text { Francis et al. (1996); } \\
\text { Abughazaleh et al. (2011) }\end{array}$ \\
\hline \multicolumn{6}{|c|}{ Independent Variables } \\
\hline \multirow{2}{*}{ 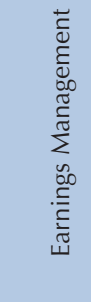 } & LEV & Leverage & $\frac{\text { Total debt }}{\text { Total Assets }}$ & Thomson $\mathbb{R}$ & $\begin{array}{c}\text { Zang (2008); } \\
\text { Abughazaleh et al. (2011) }\end{array}$ \\
\hline & CHMAN & $\begin{array}{l}\text { Change in } \\
\text { Management }\end{array}$ & $\begin{array}{c}\text { Dummy variable: } \\
1 \text { if there has been a change in } \\
\text { director/president/superintendent in } \\
\text { the year, and } 0 \text { otherwise. }\end{array}$ & $\begin{array}{c}\text { BM\&FBOVESPA } \\
\text { - Reference Form - } \\
\text { Item } 12.6 / 8\end{array}$ & $\begin{array}{l}\text { Francis et al. (1996); } \\
\text { Rield (2004); Zang (2008); } \\
\text { Abughazaleh et al. (2011) }\end{array}$ \\
\hline \multirow{6}{*}{ 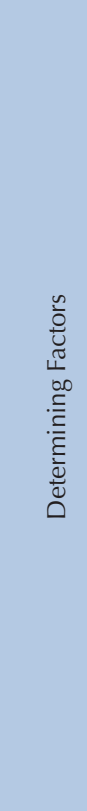 } & $\mathrm{BM}$ & Book to Market & $\begin{array}{c}(\text { Book NE }+ \text { GOODWIMP) } / \text { Market } \\
\text { Value. }\end{array}$ & Thomson $®$ & Abughazaleh et al. (2011) \\
\hline & CGU & Cash generating unit & $\begin{array}{c}\text { Dummy variable: } \\
1 \text { for two or more cash generating } \\
\text { units, and } 0 \text { for only one CGU. }\end{array}$ & $\begin{array}{c}\text { BM\&FBOVESPA } \\
\text { - Financial Statements - } \\
\text { Explanatory Notes }\end{array}$ & Abughazaleh et al. (2011) \\
\hline & REV & $\begin{array}{l}\text { Revenues (volume of } \\
\text { business) } t-1 \text { to } t\end{array}$ & $\begin{array}{c}\left(\operatorname{Rev}_{t}-\operatorname{Rev}_{t-1}\right) / T_{A}-1 \\
\operatorname{Rev}=\text { Total Revenue } \\
T A=\text { Total Assets }\end{array}$ & Thomson $®$ & Abughazaleh et al. (2011) \\
\hline & $\triangle \mathrm{OCF}$ & $\begin{array}{l}\text { Variation in } \\
\text { Operational Cash } \\
\text { Flow }\end{array}$ & $\begin{array}{c}\left(\mathrm{OCF}_{\mathrm{t}}-\mathrm{OCF}_{\mathrm{t}-1}\right) / \mathrm{TA}_{\mathrm{t}-1} \\
\mathrm{OCF}=\text { Operational Cash Flow } \\
\mathrm{TA}=\text { Total Assets }\end{array}$ & Thomson $\mathbb{R}$ & Abughazaleh et al. (2011) \\
\hline & $\triangle \mathrm{ROA}$ & $\begin{array}{l}\text { Variation in Return on } \\
\text { Total Assets }\end{array}$ & $\begin{array}{c}\left(\mathrm{EBT}_{\mathrm{t}} / \mathrm{TA}_{\mathrm{t}}\right) /\left(\mathrm{EB}_{\mathrm{T}-1} / \mathrm{TA}_{\mathrm{t}-1}\right) \\
\mathrm{EBT}=\text { Earnings Before Tax }\end{array}$ & Thomson $®$ & $\begin{array}{l}\text { Francis et al. (1996); } \\
\text { Rield (2004); Zang (2008); } \\
\text { Abughazaleh et al. (2011) }\end{array}$ \\
\hline & GOODW & Value of Goodwill & Goodwill/TA $\mathrm{t}_{\mathrm{t}-1}$ & Thomson $®$ & $\begin{array}{c}\text { Zang (2008); } \\
\text { Abughazaleh et al. (2011) }\end{array}$ \\
\hline
\end{tabular}

Source: Elaborated by the authors.

The model used in the study was adapted from the study by Abughazaleh et al. (2011). For the dependant variable (GOODWIMP) the use of a binary variable was chosen, equal to 1 for companies that GOODWIMP losses recognized in the period, and zero otherwise. The aim in this case was not to evaluate the size of the recognized loss, but rather to analyze whether or not the companies recognized such losses and which factors can explain this procedure.
Moreover, two new variables were included, Financial Leverage (LEV), in accordance with the study by Zang (2008), and Change in Management (CHMAN), as in the studies by Francis et al. (1996), Riedl (2004), and Zang (2008). Thus, financial leverage and changes in management, related to GOODWIMP loss recognition, are considered as incentives for earnings management (EM). 
Equation 1 (general model) evaluates the relationship $\triangle$ ROA, and GOODW) and the EM variables (LEV and between the determinant variables (BM, CGU, REV, $\triangle \mathrm{OCF}$,

CHMAN) with GOODWIMP losses.

$$
\text { GOODWIMP }: \alpha_{0}+\alpha_{1} \mathrm{LEV}+\alpha_{2} \mathrm{CHMAN}+\beta_{1} \mathrm{BM}+\beta_{2} \mathrm{CGU}+\beta_{3} \mathrm{REV}+\beta_{4} \Delta \mathrm{OCF}+\beta_{5} \Delta \mathrm{ROA}+\beta_{6} \mathrm{GOODW}+\varepsilon_{\mathrm{t}}
$$

To test the isolated effect of these two groups of variables (determinants and EM), two other equations were analyzed:

$$
\begin{gathered}
\text { GOODWIMP }_{\mathrm{ti}}: \alpha_{0}+\alpha_{1} \mathrm{LEV}+\alpha_{2} \text { CHMAN }+\varepsilon_{\mathrm{t}} \\
\text { GOODWIMP } \mathrm{ti}: \alpha_{0}+\beta_{1} \mathrm{BM}+\beta_{2} \mathrm{CGU}+\beta_{3} \mathrm{REV}+\beta_{4} \Delta \mathrm{OCF}+\beta_{5} \Delta \mathrm{ROA}+\beta_{6} \mathrm{GOODW}+\varepsilon_{\mathrm{t}}
\end{gathered}
$$

For treating and analyzing the data, a logistic regression for panel data was used, employing the STATA ${ }^{\bullet}$ software, considering that the dependant variable (GOODWIMP)

is a binary variable $(0$ and 1$)$ and with four periods being analyzed (2011 to 2014).

\section{DESCRIPTION AND ANALYSIS OF THE RESULTS}

In this section the description and analysis of the results are presented, in which the determining factors for GOODWIMP loss recognition were analyzed, as well as variables incentivizing earnings management via GOODWIMP.

\subsection{Descriptive statistic and correlation between study variables}

The descriptive statistic of the study variables is presented

\begin{tabular}{|c|c|c|c|c|}
\hline Variables & Minimum & Maximum & Average & Standard Deviation \\
\hline GOODWIMP & 0 & 1 & 0.064 & 0.244 \\
\hline CHMAN & 0 & 1 & 0.214 & 0.411 \\
\hline LEV & 0.00 & 0.75 & 0.297 & 0.174 \\
\hline BM & -5.98 & 119.70 & 3.876 & 10.571 \\
\hline CGU a & 0 & 1 & 0.523 & 0.500 \\
\hline REV & -1.091 & 2.852 & 0.111 & 0.256 \\
\hline$\triangle \mathrm{OCF}$ & -100.19 & 88.99 & -0.537 & 9.991 \\
\hline$\triangle \mathrm{ROA}$ & -106.47 & 410.3 & 0.772 & 22.896 \\
\hline GOODW & 0.00 & 0.75 & 0.144 & 0.158 \\
\hline
\end{tabular}
in Table 2.

Table 2 Descriptive Statistic

a $C G U=$ Cash generating unit: up to one CGU, equal to zero; two or more, equal to 1 .

Source: Elaborated by the authors.

According to Table 2 , it is observed that only around $6 \%$ of the companies in the sample presented GOODWIMP losses in the period analyzed. This result may be due to various factors: (i) the companies analyzed really did not suffer losses; (ii) the complexity of calculating losses may help to explain the low number of losses recognized; and (iii) the managers may have used discretion in the rules to avoid recognizing losses. This last question is evaluated further on. In any case, this low percentage of companies with recognized losses may adversely affect the significance of the results regarding their determinants.

The same may occur with the variable that measures changes in management (CHMAN), which presented an average of around $21 \%$. The number of cash generating units (CGU) variable presented an average of $52 \%$, which means that almost half of the companies analyzed had one CGU, 
which in a way mitigates the possibility of the managers engaging in earnings management via the allocation of goodwill to different CGUs in the company.

It is also worth noting that, on average, goodwill (GOODW) represents 14\% of the total assets of the companies investigated, which denotes its importance in the composition of these companies' assets. Thus, it is inferred that the companies may pay special attention to the management of this asset, which involves aspects related to its recognition, measurement, and reduction due to impairment (impairment losses).

With regards to the variability of the variables, it is verified that those that presented more fragmented data were book-to-market (BM), revenues (REV), variation in cash flow $(\triangle \mathrm{OCF})$, and variation in $\mathrm{ROA}(\triangle \mathrm{ROA})$.

It is also worth noting that the minimum values of the LEV and GOODW variables appear in Table $2(0.00)$ rounded to decimal places. Thus, in reality there are no companies without debt or a goodwill value in the sample, only with relatively small values for these items in relation to total assets.

Next, the correlations between all of the variables were calculated, in order to detect possible connections between the dependant variable (GOODWIMP) and the independent variables, as well as between the latter. The results are presented in Table 3.

Table 3 Analysis of correlation between variables

\begin{tabular}{|c|c|c|c|c|c|c|c|c|c|}
\hline Variables & GOODWIMP & LEV & CHMAN & BM & CGU & REV & $\triangle \mathrm{OCF}$ & $\triangle \mathrm{ROA}$ & GOODW \\
\hline GOODWIMP & 1.0000 & & & & & & & & \\
\hline LEV & -0.0776 & 1.0000 & & & & & & & \\
\hline CHMAN & $0.1241^{* *}$ & 0.0390 & 1.0000 & & & & & & \\
\hline BM & -0.0769 & -0.0389 & -0.0121 & 1.0000 & & & & & \\
\hline CGU & 0.0828 & 0.0738 & 0.0041 & -0.0300 & 1.0000 & & & & \\
\hline REV & -0.0522 & -0.0502 & -0.0415 & -0.0683 & $-0.10^{* * *}$ & 1.0000 & & & \\
\hline$\triangle \mathrm{OCF}$ & -0.0439 & 0.0210 & -0.0523 & 0.0492 & -0.0073 & 0.0719 & 1.0000 & & \\
\hline$\triangle \mathrm{ROA}$ & -0.0725 & 0.0733 & -0.0181 & $0.1275^{* *}$ & -0.0487 & 0.0018 & 0.0122 & 1.0000 & \\
\hline GOODW & $0.1558^{*}$ & $-0.3792^{*}$ & 0.0682 & -0.0700 & -0.0530 & 0.0806 & 0.0062 & -0.0077 & 1.0000 \\
\hline
\end{tabular}

${ }^{*}$ significant to $1 \% .{ }^{* *}$ significant to $5 \% .{ }^{* * *}$ significant to $10 \%$.

Source: Elaborated by the authors.

According to Table 3, a positive and significant (5\%) correlation is noted between GOODWIMP and CHMAN, consistent with study hypothesis $\mathrm{H}_{8}$, and indicating a positive relationship between a change in management and GOODWIMP loss recognition. A positive and significant (1\%) correlation was found between GOODWIMP and goodwill (GOODW), consistent with hypothesis $\mathrm{H}_{5}$ and compatible with the results from Abughazaleh et al. (2011), in that the greater the value of goodwill, the greater the risk of a company suffering losses in this type of asset.

A negative and significant (1\%) correlation is also worth noting between LEV and GOODW, indicating that companies with greater goodwill would be associated with lower levels of leverage.

Generally, the correlation coefficients found were low, the highest being between the dependent study variable
(GOODWIMP) and the LEV variable (57.8\%), although it was not significant. The other variables presented coefficients lower than $15 \%$, indicating a weak connection with GOODWIMP losses, although BM and $\triangle \mathrm{OCF}$ were significant.

\subsection{Analysis of the Determinants of GOODWIMP}

In order to test the hypotheses established in the study, a logistic regression with panel data was applied, contemplating equations 1 to 3, described in chapter 3. The Shapiro-Wilk test was employed, which indicated an abnormal distribution of data. Thus, of the three possible models for the logistic regression with panel data (fixed effects, random, and population-averaged - PA), the PA model was opted for, which is based on the "average response" of a population over each point in time. 
Table 4 Results of the logistic regression with panel data

\begin{tabular}{|c|c|c|c|}
\hline Variables & Eq. 1 & Eq. 2 & Eq. 3 \\
\hline Const. & -3.6817 & -2.6878 & -3.5220 \\
\hline LEV & -0.6756 & -1.1184 & \\
\hline CHMAN & $1.0324^{*}$ & $0.9422^{*}$ & \\
\hline BM & $-0.1145^{* * *}$ & & $-0.1125^{* * *}$ \\
\hline CGU & $0.7520^{* * *}$ & & $0.6756^{* * *}$ \\
\hline REV & -1.1135 & & -1.2200 \\
\hline$\triangle \mathrm{OCF}$ & 0.0121 & & 0.0090 \\
\hline$\triangle \mathrm{ROA}$ & $-0.0268^{*}$ & & $-0.0191^{* *}$ \\
\hline GOODW & $3.3996^{* *}$ & & $3.7878^{*}$ \\
\hline Shapiro-Wilk & $0.0848^{*}$ & $0.6606^{*}$ & $0.0982^{*}$ \\
\hline Wald chi2 & $49.28^{*}$ & $8.60^{* *}$ & $41.30^{*}$ \\
\hline observations & 346 & 346 & 346 \\
\hline groups & 91 & 91 & 91 \\
\hline
\end{tabular}

${ }^{*}$ significant to $1 \% .{ }^{* *}$ significant to $5 \% .{ }^{* * *}$ significant to $10 \%$.

Source: Elaborated by the authors.

The results from Table 4 demonstrate that the general model (equation 1), which includes all of the study variables (determinants related to economic factors and incentives for $\mathrm{EM}$ ), was significant to $1 \%$, presenting the variables CHMAN (positive relationship), BM (negative relationship), CGU (positive relationship), $\triangle \mathrm{ROA}$ (negative relationship), and GOODW (positive relationship) as being significantly related to GOODWIMP.

By testing the model that took only incentives for EM variables into account (equation 2), the results indicated a change in management (CHMAN) as positively related with GOODWIMP losses, confirming the result obtained for this variable in equation 1 , as well as the positive relationship observed in Table 3 (correlation). Thus, it is possible to infer that changes in management are associated with GOODWIMP loss recognition, which can represent EM practices, as indicated in the literature.

The model that took only determinant variables related with economic factors (equation 3) into consideration was significant (1\%), again with the same significant variables found in equation 1 .

An additional test (not presented in Table 4) was carried out excluding the GOODW variable in model 1 and 3, since it is considered that this variable has an obvious and expected relationship with GOODWIMP. This test served to identify possible Type I errors, where null hypotheses are rejected when they are true, or Type II errors, where false hypotheses cannot be rejected. The results indicated a reduction in the general explanatory power of the models, although they have been shown to be significant. Moreover, all the other variables presented the same behavior in relation to models 1 and 3, with the exception of the CGU variable, which lost significance. Considering that the coefficient for the GOODW variable in Table 4 was the greatest among the variables tested (Eq. $1=3.3996$ and Eq. $2=3.7878$ ), it is understood that its exclusion in models 1 and 3 may cause a Type I error in relation to the CGU variable.

Thus, it is possible to infer that the companies' bookto-market (BM) coefficient was negatively related to GOODWIMP loss recognition. This result supports that found in Table 3 (correlation) but contradicts hypothesis $\mathrm{H}_{1}$, founded on the studies by Zang (2008) and Abughazaleh et al. (2011). It was expected that the closer book NE is to the market value of a company, the greater the likelihood that its assets could be overvalued or not be totally recoverable. In this case, the first asset to be devalued due to impairment within a cash generating unit would be goodwill (CPC15). However, the small number of GOODWIMP losses identified in the sample (only around 6\%) may have influenced in this hypothesis not being confirmed.

With regards to the CGU variable, the positive and significant (10\%) relationship found is in line with that indicated in the literature, in which companies with more CGUs carry out more tests (Schneider, 2001) and may increase GOODWIMP losses, allocating most goodwill to units that have lower recoverable values than their accounting values (Abughazaleh et al., 2011). Thus, study hypothesis $\mathrm{H}_{2}$ is confirmed.

Study hypothesis $\mathrm{H}_{5}$ was also confirmed in verifying a positive and significant relationship between goodwill and GOODWIMP losses. As indicated by Zang (2008), the greater the value of goodwill, the greater the risk of a 
company incurring impairment losses involving this asset.

The $\triangle \mathrm{ROA}$ variable, related significantly and negatively to GOODWIMP losses, supports the literature that indicates that companies with higher returns on assets are more highly valued by the market, raising the fair value of their assets and reducing the likelihood of GOODWIMP losses (Francis et al., 1996; Zang, 2008). Thus, it was possible to confirm study hypothesis $\mathrm{H}_{6}$.

The other hypotheses $\left(\mathrm{H}_{3}, \mathrm{H}_{4}\right.$, and $\left.\mathrm{H}_{7}\right)$ were rejected due to significant coefficients not being found. These results are consistent with the studies by Abughazaleh et al. (2011) in relation to $\mathrm{H}_{3}$, by Abughazaleh et al. (2011) in relation to $\mathrm{H}_{4}$, and by Zang (2008) and Abughazaleh et al. (2011) related to $\mathrm{H}_{7}$.

The result of this study is similar to that found by Hayn and Hughes (2006), who found little evidence of GOODWIMP in financial statements. Similarly, this study found that there were few companies that recognized and reported GOODWIMP.

\subsection{Robustness Tests}

In order to test the robustness of the results, first an impairment losses in other assets (IMP) variable was included in the general model (equation 1), which aimed to verify whether recognition of such losses would end up influencing companies to also assume goodwill losses.

In another test, the aim was to measure the effect of joint economic variables in order to verify whether the effect of economic crises, inflation, and other market questions affected the recognition of such losses. Three variables were included in the general model (equation 1): inflation (IPCA), variation in Gross Domestic Product (GDP), and variation in the Ibovespa index (IBOVESPA).

In both tests the results remained similar to those found in the original model, with the CHMAN (positive relationship), BM (negative relationship), CGU (positive relationship), $\triangle \mathrm{ROA}$ (negative relationship), and GOODW (positive relationship) variables being significantly related to GOODWIMP, as observed in model 1 . The variable included in the model (IMP) was not significant, allowing it to be inferred that impairment losses in other assets are not related to GOODWIMP loss recognition.

Another test that was carried out consisted of substituting the GOODWIMP dependant variable with the IMP variable, in order to verify whether the variables tested would explain loss recognition in other assets besides goodwill. The results demonstrated that no variable in the model was significant, indicating that impairment loss recognition in other assets (not goodwill) cannot be explained by the same economic factors and EM incentives used for GOODWIMP.

\section{FINAL REMARKS}

The aim of this study was to verify the determinants of goodwill impairment loss recognition. A descriptive, documental, and quantitative study was carried out, with data from Brazilian companies listed on the Thomson database, from 2011 to 2014. The study sample totaled 91 companies, with 346 observations. The results demonstrated that the factors change in management (CHMAN), book-to-market $(\mathrm{BM})$, number of cash generating units (CGU), variation in return on assets $(\triangle \mathrm{ROA})$, and goodwill (GOODW) were significant in determining GOODWIMP losses.

The first implication of this result is that there are indications that the sample companies have used GOODWIMP losses for earnings management, considering one of the two proxies used in the study to capture such behavior (CHMAN). It is concluded that a change in management was positively related to GOODWIMP losses, as predicted in contracts theory (Watts \& Zimmerman, 1986,1990; Holthausen, 1990; Christie \& Zimmerman, 1994).

Indebtedness was not related to EM practices via GOODWIMP loss recognition, as could be predicted based on the level of debt hypothesis (Watts \& Zimmerman, 1986). However, it is important to highlight that the reduced number of companies with recognized GOODWIMP may have contributed to bias in this result.

The result for the $\mathrm{BM}$ variable also warrants reflection, since the negative and significant relationship between BM and GOODWIMP, contrary to the literature, may represent that the companies analyzed made use of GOODWIMP losses in an opportunistic way in order to manage earnings, for example instead of recognizing some economic damage suffered by their assets, which would effectively affect the recoverability of goodwill. However, this aspect was not investigated in this study, thus constituting an opportunity for future research.

Moreover, it is necessary to contrast the result for the $\mathrm{BM}$ variable with that of the $\triangle \mathrm{ROA}$ variable. It was noted that companies with greater variations in return on assets were less likely to recognize goodwill losses. Generally, such companies may be more highly valued by the market, which would raise the fair value of their assets, and could consequently result in a lower book-to-market. Therefore, it is concluded that the positive relationship predicted in the literature between BM and GOODWIMP may be affected by variations in company returns $(\triangle \mathrm{ROA})$. 
Another finding of the study is that the number of cash generating units can contribute to companies managing their recognition or not of GOODWIMP losses, allocating goodwill to loss-making CGUs and thus raising the losses recognized.

Moreover, a positive relationship was observed between goodwill and impairment losses in this asset, proving the expected natural relationship between the value of an asset and the likelihood of possible losses being recognized. However, as well as this natural relationship, it is possible that the value of goodwill is being overvalued by companies, leading to loss recognition, which was not investigated in this study, but could be the subject of future research, thus constituting another research opportunity.

The other variables tested did not show a significant relationship with GOODWIMP. However, considering the results from various previous studies, the relatively short timeline for analysis of this procedure in Brazil, and taking into account the adoption of international accounting standards, it is not possible to discard that new studies may find such relationships in the future.

In light of this, it is generally concluded that the GOODWIMP losses recognized in the companies analyzed were determined by economic factors, with the exception of variations in cash flow and revenues, as well as incentives for EM such as changes in management.

In terms of the contribution made by this article to the area of study, the results found with regards to the EM incentive variables (LEV and CHMAN) stand out, which on an international level (Zang 2008; Abughazaleh et al., 2011) were shown to be related to GOODWIMP loss recognition, which was verified on a national level only in the relationship with CHMAN. This finding may indicate that managers, in taking on a new company, use the complexity and subjectivity of the calculation of recoverable goodwill value in order to act opportunistically, managing their earnings.

Moreover, the results of this study serve as an prompt for studies on companies from different countries, since the determinant variables of GOODWIMP may be influenced by each country's context. Given the limitation of the sample, both in the number of companies and in the timeframe of the analysis, the inclusion of new analysis periods (2015 onward) is suggested, as well as other variables that could influence both GOODWIMP loss recognition and its use for earnings management, such as corporate governance mechanisms, for example.

\section{References}

Abughazaleh, N. M., Al-Hares, O. M., \& Roberts, C. (2011). Accounting discretion in goodwill impairments: UK evidence. Journal of International Financial Management \& Accounting, 22(3), 165-204.

Albani, P. C., \& Almeida, J. E. F. (2012). Teste de Impairment de ativos: Análise comparativa da evidenciação das companhias abertas listadas no Novo Mercado por setor da economia e auditorias. In Anais do $9^{\circ}$ Congresso USP de Iniciação Científica em Contabilidade, São Paulo, SP, Brasil.

Alciatore, M., Easton, P., \& Spear, N. (2000). Accounting for the impairment of long-lived assets: evidence from the petroleum industry. Journal of Accounting and Economics, 29(2), 151-172.

Amaro, H. D., Bachmann, R. K. B., \& Fonseca, M. W. (2013). Impairment e alisamento de resultados: um estudo em companhias do setor de energia elétrica listadas na BM\&FBOVESPA. In Anais do XVI SEMEAD - Seminários em Administração, São Paulo, SP, Brasil.

Andersson, S., \& Wenzel, F. (2014). Application of IAS 36 - Impairment of fixed assets. A qualitative study about the main challenges for companies regarding impairments (Degree Project for Master of Science). School of Business, Economics and Law, University of Gothenburg, Sweden: Retrieved from http://papers.ssrn.com/sol3/ papers.cfm?abstract_id=https://gupea.ub.gu.se/handle/2077/36044

Assaf, A., Neto (2012). Finanças corporativas e valor (6a ed.). São Paulo: Atlas.

Barbosa, J. S., Consoni, S., Scherer, L. M., \& Clemente, A. (2014). Impairment no Goodwill: uma Análise Baseada na Dịvulgação Contábil. Revista de Educação e Pesquisa em Contabilidade (REPeC), 8(2), 159-179.

Chen, L., \& Zhao, X. S. (2004). Understanding the role of the market-tobook ratio in corporate financing decisions. Social Science Research Network, 1-54. Retrieved from http://papers.ssrn.com/sol3/papers. cfm?abstract_id $=538944$

Christie, A. A., \& Zimmerman, J. L. (1994). Efficient and opportunistic choices of accounting procedures: corporate control contests. The Accounting Review 69(4), 539-566.
Comitê de Pronunciamentos Contábeis [CPC] (2010). Pronuinciamento Técnico CPC 01(R1) - Redução ao Valor Recuperável de Ativos. Retrieved from http://www.cpc.org.br/CPC/Documentos-Emitidos/ Pronunciamentos/Pronunciamento? $\mathrm{Id}=2$.

Comitê de Pronunciamentos Contábeis (2010). Pronunciamento Técnico CPC 04 (R1) - Ativo Intangível. Retrieved from http:// www.cpc.org.br/CPC/Documentos-Emitidos/Pronunciamentos/ Pronunciamento? $\mathrm{Id}=35$.

Comitê de Pronunciamentos Contábeis (2011). Pronunciamento Técnico CPC 15 (R1) - Combinação de Negócios. Retrieved from http:// www.cpc.org.br/CPC/Documentos-Emitidos/Pronunciamentos/ Pronunciamento? $\mathrm{Id}=46$.

Duh, R. R., Lee, W. C., \& Lin, C. C. (2009). Reversing an impairment loss and earnings management: The role of corporate governance. The International Journal of Accounting, 44(2), 113-137.

Francis, J., Hanna J. D., \& Vincent L. (1996). Causes and Effects of Discretionary Asset Write-Offs. Journal of Accounting Research, 34, 117-134.

Gu, F., \& Lev, B. (2011). Overpriced shares, ill-advised acquisitions, and goodwill impairment. The Accounting Review, 86(6), 1995-2022.

Hayn, C., \& Hughes, P. J. (2006). Leading indicators of goodwill impairment. Journal of Accounting, Auditing \& Finance, 21(3), 223265.

Holthausen, R. W. (1990). Accounting method choice: opportunistic behavior, efficient contracting, and information perspectives, Journal of Accounting and Economics, 12(1-3), 207-218.

Iudícibus, S., Martins, E., Gelbcke, E. R., \& Santos, A. (2010). Manual de Contabilidade Societária: Aplicável a todas as sociedades de acordo com as normas internacionais e do CPC. São Paulo: Atlas.

Jarva, H. (2009). Do firms manage fair value estimates? An examination of SFAS 142 goodwill impairments. Journal of Business Finance \& Accounting, 36(9-10), 1059-1086.

Lander;:G. H., \& Reinstein, A. (2003). Models to measure goodwill impairment. International Advances in Economic Research, 9(3), 227-232. 
Li, Z., Shroff, P. K., Venkataraman, R., \& Zhang, I. X. (2011). Causes and consequences of goodwill impairment losses. Review of Accounting Studies, 16(4), 745-778.

Machado, E. A., Cruz, A. P. C., Takamatsu, R. T., \& Lima, G. A. S, F. L: (2013). Evidências de disclosure de valor recuperável de ativos em firmas listadas no mercado acionário brasileiro. Revista Universo Contábil, 9(1), 86-103.

Martinez, A. L. (2006). Minimizando a variabilidade dos resultados contábeis: estudo empírico do income smoothing no Brasil. Revista Universo Contábil, 2(1), 9-25.

Meeting, D. T., \& Luecke, R. W. (2002). Asset impairment and disposal. Journal of Accountancy, 193(3), 49-60.

Niyama, J. K., Rodrigues, A. M. G., \& Rodrigues, J. M. (2015). Algumas Reflexões sobre Contabilidade Criativa e as Normas Internacionais de Contabilidade. Revista Universo Contábil, 11(1), 69-87.

Olante, M. L. (2013). Overpaid acquisitions and goodwill impairment losses - Evidence from the US. Advances in Accounting, 29(2), 243254.

Peetathawatchai, P., \& Acaranupong, K. (2012). Are impairment indicators and losses associated in Thailand? Journal of Financial Reporting and Accounting, 10(1), 95-114.

Petersen, C., \& Plenborg, T. (2010). How do firms implement impairment tests of goodwill? Abacus, 46(4), 419-446.

Pinheiro, V. R. D. A. (2014). O tratamento contabilístico do goodwill nas empresas do PSI-20. 2014. (Master's Degree). Instituto Politécnico do Porto, Instituto Superior de Contabilidade e Administração do Porto, Porto, Portugal.

Raupp, F. M., \& Beuren, I. M. (2006). Proposta de mensuração de ativos imobilizados por meio do fair value e do impairment test. In Anais do $6^{\circ}$ Congresso de Controladoria e Contabilidade, Universidade de São Paulo, São Paulo, SP.

Riedl, E. J. (2004). An Examination of Long-Lived Asset Impairments. The Accounting Review, 79(3), 823-852.

Santos, A. S. A., Dani, A. C., \& Klann, R. C. (2015). Concentração de
Propriedade e o Impairment Loss sobre o Goodwill: Investigação Empírica no Contexto das Companhias Abertas Brasileiras. Revista Facultad de Ciencias Económicas: Investigación y Reflexión, Universidad Militar Nueva Granada 23(1), 175-188.

Santos, J. L. D., Schmidt, P., \& Machado, N. P. (2003). Teste de" impairment" para ativos de longa duração: tratamento contábil de acordo com o SFAS no 144. Contexto, 3(5), 99-121.

Schneider, C. (2001).. Four ways to say goodbye to goodwill amortization: expert tips for tackling the impairment test. Retrieved from http:// www.cfo.com/article.cfm/2997501? $\mathrm{f}=$ related.

Seetharaman, A., Sreenivasan, J., Sudha, R. \& Yee, T. Y. (2006). Managing impairment of goodwill. Journal of Intellectual Capital, 7(3), 338-353.

Souza, M. M. de. (2011). Perda no valor recuperável de ativos: fatores explicativos do nível de evidenciação das empresas de capital aberto brasileiras. (Master's Degree): Centro Socioeconômico da Universidade Federal de Santa Catarina, Florianópolis, SC, Brasil.

Souza, M. M. de, Borba, J. A., \& Zandonai, F. (2011). Evidenciação da perda no valor recuperável de ativos nas demonstrações çontábeis: uma verificação nas empresas de capital aberto brasileiras. Contabilidade Vista \& Revista, 22(2), 67-91.

Strong, J. S., \& Meyer, J. R. (1987). Asset writedowns: Managerial incentives and security returns. The Journal of Finance, 42(3), 643661.

Watts, R. L., \& Zimmerman, J. L. (1986). Positive accounting theory. New Jersey: Prentice-Hall.

Watts, R. L., \& Zimmerman, J. L. (1990). Positive accounting theory: a ten year perspective, The Accounting Review, 65(1), 131-156.

Zandonai, F., \& Borba, J. A. (2009). O que dizem os achados das pesquisas empíricas sobre o teste de impairment: uma análise dos joùrnals em língua inglesa. Contabilidade, Gestão e Governança, 12(1), 24-34.

Zang, Y. (2008). Discretionary behavior with respect to the adoption of SFAS no. 142 and the behavior of security prices. Review of Accounting and Finance, 7(1), 38-68.

\section{Correspondence Address:}

Mara Vogt

Universidade Regional de Blumenau, Programa de Pós-Graduação em Ciências Contábeis

Rua Antonio da Veiga, 140, Sala D-202 - CEP: 89.012-900

Vitor Konder - Blumenau - SC

Email: maravogtcco@gmail.com 